\title{
Powerful or Powerless? Chief Online Education Officers' Legitimate Power over Online Program Quality in U.S. Higher Education Institutions
}

\author{
Georgianna Laws \\ Maryville University
}

\begin{abstract}
As the online higher-education market continues along its trajectory of steady growth, it becomes increasingly competitive. Since quality sets online programs apart in the current competitive market, it is a priority for higher-education institutions. Consequently, presidents/chancellors and provosts at many U.S. higher education institutions have been placing the quality of online program administration under the purview of a new role known under the umbrella term of chief online education officer (COEO). However, when looking for empirical research to help calibrate the COEO role in a way that maximizes its influence on quality, senior leaders find a gap in the literature. The purpose of this quantitative, correlative, non-experimental study was to ask COEOs from all over the nation to use the Online Learning Consortium Quality Scorecard (QSC) to share their perceptions of the quality of their institution's online program. Additionally, COEOs were asked to self-assess their ability to influence quality based on their legitimate power and to describe environmental factors that could potentially impact their legitimate power. Key findings indicate a strong, positive correlation between overall legitimate power and overall quality, as well as between overall legitimate power and the hierarchy of COEO job titles (E1). Additional environmental factors significantly correlated with legitimate power categories included the number of units making a full report to the COEO (E3) and the breadth of COEO's current portfolio of responsibilities (E12), among others. Finally, data indicate that the hardest quality category to influence is technical support.
\end{abstract}

Keywords: higher education leadership, online program, quality assurance, OLC Quality Scorecard, legitimate power, environmental factors

Laws, G. (2021). Powerful or powerless? Chief online education officers' legitimate power over online program quality in U.S. higher education institutions. Online Learning, 25(2), 120-139. https://doi.org/10.24059/olj.v25i2.2101 


\section{Powerful or Powerless? Chief Online Education Officers' Legitimate Power over Online Program Quality in U.S. Higher Education Institutions}

Quality is a key element of online education (Irele, 2013; Palloff \& Pratt, 2005; Quality Matters, 2017). Online education is firmly entrenched in mainstream higher education (Allen \& Seaman, 2004; Allen et al., 2016). Competition for online students has skyrocketed, making quality assurance paramount for educational institutions in the $21^{\text {st }}$ century (Fredericksen, 2017; Herron, Lashley, Salley, \& Shaw, 2016; Legon \& Garrett, 2017; 2018; Legon, Garrett, \& Fredericksen, 2019). Consequently, in the last decade, higher education presidents/chancellors and provosts across the nation started establishing a position known under the umbrella term of "chief online education officer" (Legon \& Garrett, 2017, p. 8), or COEO for short. This professional's sole focus is the administration and quality of online education (Fredericksen, 2017; Legon \& Garrett, 2017).

Since COEOs are at the heart of online education "issues and influences that determine present and future policy" (Legon \& Garrett, 2017, p. 8), they hold legitimate power over quality assurance efforts. "Legitimate power" is synonymous with positional power or formal authority, and refers to the power derived from having formal job authority or jurisdiction over certain areas of responsibility, much like a judge has the authority to administer sentences in a courtroom (French \& Raven,1959a, 1959b; Lunenburg, 2012).

While research already exists on COEOs and their institutions' unique environmental characteristics, online program quality, and legitimate power, these topics have been studied in isolation (Fredericksen, 2017, 2018; French \& Raven,1959a, 1959b; Herron et al., 2016; Irele, 2013; Legon \& Garrett, 2017; 2018; Legon, Garrett, \& Fredericksen, 2019; Lunenburg, 2012; Shelton, 2010). There is a scarcity of research on the legitimate power COEOs hold over their institutions' online program quality. Similarly, little is known about whether institutional environments influence COEO's legitimate power. This leaves a gap in the literature when it comes to research that can inform the practice of U.S. online education leadership (Huett \& Piña, 2016; Legon \& Garrett, 2018; Piña, Lowell, \& Harris, 2018). Without research as a guide, U.S. higher education presidents/chancellors and provosts cannot accurately calibrate COEO job descriptions as they do not have evidence available to inform the amount of legitimate power necessary to enable their COEO to maximize online program quality at their institution.

The purpose of this study was to link existing online program quality, legitimate power, and environmental characteristics to the COEO role in the United States. More specifically, the study aimed to:

- describe the relationship between COEOs' legitimate power landscape and their ability to influence quality and

- investigate how environmental factors impact the COEO's legitimate power.

\section{Research Questions}

The study chose methodology and survey instruments to address the following research questions:

1. Is there a statistically significant correlation between COEOs' overall legitimate power and overall online program quality, as self-assessed by COEOs using the Quality Scorecard (QSC)? 
2. Is there a statistically significant correlation between COEOs' perceived overall legitimate power and COEO-reported environmental factors?

\section{Review of Related Literature}

To gain a better understanding of the research problem, it is necessary to reflect on the literature gap at the intersection of the COEOs' legitimate power, the quality assurance efforts by the institutions' online education programs, and the unique environment of higher education institutions in the United States.

\section{Quality}

"Quality" in online education is a complex and mysterious term - a "black box" (Adair \& Diaz, 2014, p. 5) obscuring the contents of educational inputs and outputs taking place in the classroom (Latchem, 2014; Mitchell, 2009; Shattuck, 2014; Shelton \& Saltsman, 2005). The same obscuring of contents can be observed at the online program level. "Many institutions" notes Shelton (2010b, p. 60), "prolifically advertise they offer quality online education but have not had a way to quantify or benchmark their programs." Shelton also noted that "the literature has focused on the quality of teaching and pedagogy far more than the overall quality of programs" (2010a, p. 34 ), which left online program administrators unable to ascertain the quality of online education, support strategic planning, or guide program improvements (Shelton \& Saltzman, 2005; Shelton, 2010a).

In response to this challenge, Shelton built on the 24 Institute for Higher Education Policy quality indicators through a six-round Delphi research study conducted with 43 experts (Merisotis \& Phipps, 2000; Shelton, 2010a). Through this process, nine quality categories emerged, each comprised of one or more quality indicators scored on a scale of zero (deficient) to three (exemplary; OLC, 2018). The resulting instrument is what we know today as the Online Learning Consortium's QSC instrument (Shelton, 2010a).

One of the future recommendations Shelton offered through her Delphi study was for other investigators to conduct research "with a group of online education administrators who would use the scorecard to self-assess their own online programs and report their findings" (2010a, p. 172). This study enacted those recommendations and invited COEOs to self-assess their institution's online programs through the lens of the QSC.

\section{COEOs}

The earliest publication on this topic was an article on the type of distance education leadership needed in the $21^{\text {st }}$ century (Beaudoin, 2003). Many institutions began adopting a COEO role around the year 2010, leading to intensified research regarding this role (Fredericksen, 2017). In 2012, an article was published about the types of leadership theories applicable to COEO-like roles in higher education (Nworie, 2012). In 2016, a team of researchers published an article describing what it takes for one to fulfill the duties of a COEO-type role as well as what this leader's promotional prospects may be (Herron et al., 2016). A year later, two publications came out: one offered a composite description of COEOs serving in 4-year institutions in America and the other captured the current landscape of online education (Fredericksen, 2017; Legon and Garrett, 2017). In 2018, two sequel publications added to the literature: one offered a composite description of COEOs serving in 2-year institutions in America and the other, again, captured the current landscape of online education (Fredericksen, 2018; Legon \& Garrett, 2018). This latter 
article was the first to connect jurisdiction or legitimate power with COEOs' ability assure quality at the program level. The latest addition to the COEO literature is the third survey to capture the current landscape of online education (Legon, Garrett, \& Fredericksen, 2019).

In light of the persistent visibility and growth of eLearning, presidents/chancellors and provosts created the COEO role to direct organizational innovation of strategic importance and to absorb all duties associated with online education, including mission, accreditation, course scheduling, quality assurance, curriculum, technology, faculty needs, and resources (Herron et al., 2016; Fredericksen, 2017; Legon \& Garrett, 2017). The COEO functions "beyond middle management, offering an institution-wide strategic vision as part of senior academic leadership" (Herron et al., 2016, p. 1), and sits "at the center of the issues and influences that determine present and future [online education] policy" (Legon \& Garrett, 2017, p. 8).

\section{COEO Environmental Factors}

Existing literature mentions environmental factors that shape the $\mathrm{COEO}$ role at each unique higher education institution. These contextual elements include job title, reporting line, reporting units, length of the role at the institution, length of time as COEO at the current institution, type and length experience, portfolio of responsibilities, and leadership responsibilities.

Job Titles. The literature refers to the COEO-type role in several ways: online learning leader, chief online officer, chief online learning officer, and, of course, chief online education officer (Fredericksen, 2017, 2018; Herron et al., 2016; Legon \& Garrett, 2017; 2018; Legon, Garrett, \& Fredericksen, 2019). In the higher education arena, those who identify as COEOs hold a variety of unique titles (Fredericksen, 2017; Legon \& Garrett, 2017), such as "Coordinator of Distance Learning, Director of Distance Education, Dean of Distance and Continuing Education, Director of E-Learning, Director of Instructional Technology and Distance Learning, Dean of Online Learning, or Assistant/Associate Vice President for Distance Education" (Nworie, 2012, p. $3)$.

Upstream Reporting Line. The 2017 and 2018 Fredericksen, twin, national studies indicated COEOs report upstream through the provost/chief academic officer or another senior academic leader in $75 \%$ of universities, compared to $61 \%$ of community colleges. Community college COEOs are two-times more likely to report upstream through the dean of a school (7\%) compared to university COEOs (3\%) and, similarly, twice as likely to report through a nonacademic vice president/senior vice president (14\%) compared to their university counterparts (7\%). In both types of institutions, a small number of COEOs (3\% in community colleges and $5 \%$ in universities) report through the chief information officer, giving some validity to the view that online education is an academic rather than an IT function (Fredericksen, 2017, 2018).

Lastly, in both types of institutions, only $5 \%$ report directly to a president (Fredericksen, 2017). Other sources indicate $10 \%$ of higher education COEOs reported to the president in 2017, increasing to $15 \%$ in 2018 (Legon \& Garrett, 2017; 2018). Ray Schroeder, UPCEA Director for the Online Leadership Center \& Associate Vice Chancellor of Online Learning at the University of Illinois Springfield, advocates for COEOs to report directly to the president or chancellor and to be accepted by the chief officer leadership suite (Herron et al., 2016). Mike Abbiati, WICHE Vice President and WCET Executive Director, also believes it is critical for the COEO to work on equal footing with the $\mathrm{CIO}$ and $\mathrm{CFO}$ and to have the support of the president (Herron et al., 2016). 
Downstream reporting line. In over $50 \%$ of higher education institutions, the following report to the COEO role: instructional design, course design and multimedia development, faculty development and training, learning management systems, online learning policy development, and academic/education technology units (Fredericksen, 2017, 2018). Less common are reports from the center for teaching and learning, faculty IT support, faculty library support, student services, advising, marketing, or educational research units (Fredericksen, 2017, 2018). The COEO, therefore, is "not bound to a single discipline in particular but to effective learning practices in general" (Herron et al., 2016, p. 3).

Introduction of the COEO Role at the Institution. Recent national surveys indicate the earliest adoption of the COEO role occurred a decade or more ago in $29 \%$ of 4-year institutions compared to $39 \%$ of 2-year institutions (Fredericksen, 2017, 2018). Similarly, the latest adoption of the COEO role (less than year) was reported in $6 \%$ of universities compared $2 \%$ of community colleges (Fredericksen, 2017; 2018). This finding suggests administrators at 2-year institutions were quicker than their 4-year counterparts to introduce the COEO-type role.

COEO Responsibilities. COEOs could be responsible for the mission, accreditation, student demand, quality assurance curriculum, technology, faculty needs, and well as the resources related to online education (Legon \& Garrett, 2017). Half of COEOs hold a faculty appointment in addition to their online leadership role; those faculty appointments are split roughly evenly between tenure/tenure track and non-tenure appointments (Fredericksen, 2017).

\section{Legitimate Power}

This study examines the COEO's effectiveness in assuring online program quality in terms of legitimate power, which refers to "a person's ability to influence others' behavior because of the position that person holds within the organization" (Lunenburg, 2012, p. 2). This type of power is derived from having jurisdiction over certain areas of responsibility and is thus sometimes referred to as positional power or formal authority (French \& Raven,1959a, 1959b; Lunenburg, 2012). Research on legitimate power emerged from the work of French and Raven, who identified six bases of power through which leaders influence others' attitudes, values, or behaviors: (a) legitimate: the leader has formal authority on the job, (b) reward: the leader can provide rewards to followers, (c) coercive: the leader can reprimand the followers, (d) information: the leader possesses information that followers need, (e) expert: followers perceive the leader's competence, and (f) referent: followers identify with and like the leader (French and Raven, 1959b; Raven, 1965). While the French and Raven framework is still relevant and popular in the $21^{\text {st }}$ century, it has been criticized for suggesting the relationship between the six power bases and subordinate outcome variables can account for all organizational circumstances (Hersey, Blanchard, \& Johnson, 2008; Kipnis \& Schmidt, 1983; Kipnis, Schmidt, \& Wilkinson, 1980; Matteson \& Ivancevich, 1998; Podsakoff \& Schriesheim, 1985; Robbins, 2009; Thompson, 2003).

French and Raven (1959a) see power in terms of influence and see influence in terms of psychological change. French and Raven represented influence as the relationship between followers, a leader in a specific a role (such the COEO), and group norms. Legitimate power to French and Raven, therefore, means the followers' internalized values dictate that the leader has a legitimate right to influence followers and that followers must accept the leader's influence. The authors believe legitimacy involves standards accepted by followers through which the leader can assert his or her power. French and Raven note followers see the leader as being justified in prescribing behavior since he or she has been granted that power by a legitimizing agent accepted 
by the followers. This concept is similar to how a department leader accepts a vice president's authority by virtue of the facts that the vice president's power has been delegated by the president and that the vice presidency itself (as an office) holds a certain range of legitimate power. If the leader uses his or her legitimate power outside of the range of influence accepted by followers, such action will be considered illegitimate and erode the leader's desirability (French \& Raven, 1959a).

\section{Theoretical Framework}

The study employed two theories which informed the questions asked relative to legitimate power and environmental factors: bureaucracy and contingency.

\section{Bureaucracy}

Legitimate power and the role of the COEO are bureaucratic constructs. Max Weber, "the father of bureaucracy" (Manning, 2013, p. 113), asserted that organizations represent rational, precise, and efficient ways to meet goals. Bureaucracies are hierarchical in nature (Birnbaum, 1989); the COEO represents the apex of the online-education chain of command, sits side-by-side with fellow chief officers, and reports to a senior leadership role, such as the president or provost. COEOs may implement change using their formal legitimate power. The theory of bureaucracy influenced the survey questions asked of the study participants, such as what their title is, to whom they report, and which units report to them.

\section{Contingency}

According to contingency theory, there is no ideal way to manage organizations. The effectiveness of an organization, therefore, resides in the close alignment between its design and environment (Lawrence \& Lorsch, 1967). Furthermore, this theory holds that the degree of complexity of the environment should match the complexity of processes and structures (Birnbaum, 1989); the more complex the environment, the more important it becomes for the organization to balance high degrees of differentiation (the organization's segmentation into subsystems with unique attributes) and integration (unity of effort among the organization's subsystems toward the completion of institutional tasks). This theory informed the survey questions related to environmental factors of potential consequence to a COEO's legitimate power.

\section{Methods}

The choice of a sample for this study is rooted in the history of past studies of this population. The seminal studies conducted by Dr. Eric Fredericksen captured samples of individuals from 4-year and 2-year institutions representing, public, private, for-profit, and nonprofit institutions across the nation (Fredericksen, 2017, 2018). The Herron research team analyzed all published COEO-type job descriptions for higher education in the nation and interviewed several leaders in the field (Herron, et al., 2016). Finally, the authors of the Changing Landscape of Online Education (CHLOE) studies captured 104 individuals through CHLOE 1, 182 through CHLOE 2, and 280 through CHLOE 3 - all COEOs from public, private, non-profit, and for-profit 2- and 4-year institutions with Quality Matters and Eduventures membership (Legon \& Garrett, 2017; 2018; Legon, Garrett, Fredericksen, 2019). Consequently, this national study also included COEOs representing public, private, non-profit, and for-profit 2- and 4-year institutions to remain in line with past studies conducted on this population. 
To take part in the study, participants had to be currently employed as a COEO by a U.S. higher education institution of any type (public or private, for-profit or nonprofit, and 2- or 4year), where COEO represents the highest role on the organization chart to focus on online education. Excluded from participation were those who (a) were not the only individual in a COEO role at their institution, (b) served as a COEO in the past, (c) served as COEO in the corporate world (i.e., outside the confines of higher education), or (d) were employed outside the United States.

The researcher made the following four assumptions in designing the study: (a) all institutions with an online program have an individual with COEO responsibilities, (b) there is only one COEO at each higher education institution, (c) COEOs are knowledgeable about their institution's environment and online program quality, and (d) COEOs have legitimate power over at least one QSC criterion at their institution.

Since there is no list of all COEO-type professionals in American higher education, this study used non-probability sampling combined with convenience and snowball sampling (Fredericksen, 2017, 2018; Legon, Garrett, Fredericksen, 2019). The sample was captured via electronic advertisement through the Online Learning Consortium newsletter and social media, as well as through a list of 65 COEO emails kindly provided by the authors of the CHLOE 2017 survey. All participants were invited to share the study with other COEOs, yet were advised that each person meeting the inclusion criteria can only take the survey once.

The anonymous survey sent out in summer of 2019 first asked participants to consent to the research, should they meet the inclusion criteria and wish to participate. The second part of the survey took participants through each component in the QSC, asking COEOs to provide two sets of scores per QSC quality indicator: a QSC quality score on a scale of zero (deficient) to three (exemplary) and a corresponding legitimate power score on a scale of zero (I have no legitimate power and no input) to three (I have full legitimate power). Finally, participants answered questions about the unique environment in which they operate that could potentially impact their legitimate power.

\section{Researcher Bias}

The researcher is an administrator in online education. To minimize the potential effects of researcher bias, standard evaluation tools and instruments common to the field of online education provided the foundation for the study, and results were peer-reviewed by professional researchers.

\section{Data Analysis}

The score of each indicator within the nine QSC categories was used to construct quality and power average scores for each of the nine QSC criteria. Using averages was more appropriate than summing the individual responses because some participants skipped one or more questions. Given the sporadically incomplete data, taking the sum of the quality and power answers could have led to a lower quality or power score for COEOs who provided incomplete responses relative to COEOs who provided complete responses, resulting in a spurious relationship between quality and power. To mitigate this problem, average scores were constructed by taking the sum of the score for each QSC indicator and dividing it by the total number of QSC indicators to which respondents had non-missing values within the respective QSC criterion. After the aforementioned data "cleaning" process, the investigator used the IBM SPSS software to conduct descriptive and 
correlational analyses. Pearson's correlation was used to analyze categorical environmental variables and Spearman's rho was used to analyze ordinal environmental variables.

\section{Results}

\section{Sample Characteristics}

Table 1 indicates, most respondents were male (55\%) aged 41 or older $(75 \%)$, contrary to the samples identified in previous studies (Fredericksen, 2017; 2018), where most respondents were female $(50 \%$ and $61 \%$ respectively) aged 45 or older $(74 \%$ and $69 \%$ respectively). The majority of respondents earned a doctoral degree (65\%), which is consistent with the $62 \%$ recorded in previous studies (Fredericksen, 2017; 2018). Most COEOs do not supplement their leadership responsibilities with teaching duties (65\%), which is, again, consistent with the $50 \%$ and $69 \%$ figures recorded in previous findings (Fredericksen, 2017; 2018). The majority of respondents represented public (55\%), 4-year (64\%), nonprofit (89\%) institutions. 20 responses came from 16 states in America, with at least one state represented in the Northeastern (20\%), Midwestern (30\%), Southern (45\%), and Western (5\%) regions.

\section{Table 1}

Frequencies and Percentages for Sample Characteristics

\begin{tabular}{|c|c|c|c|}
\hline & iple Characteristics & $n$ & Percentage \\
\hline \multicolumn{4}{|c|}{ Gender } \\
\hline & Female & 9 & $45 \%$ \\
\hline & Male & 11 & $55 \%$ \\
\hline \multicolumn{4}{|l|}{ Age } \\
\hline & $18-30$ & 0 & $0 \%$ \\
\hline & $31-40$ & 5 & $25 \%$ \\
\hline & $41-50$ & 7 & $35 \%$ \\
\hline & $51-60$ & 5 & $25 \%$ \\
\hline & $61-70$ & 3 & $15 \%$ \\
\hline & Over 71 & 0 & $0 \%$ \\
\hline \multicolumn{4}{|c|}{ Highest Degree Earned } \\
\hline & Bachelor's & 0 & $0 \%$ \\
\hline & Master's & 7 & $35 \%$ \\
\hline & Specialist's & 0 & $0 \%$ \\
\hline & Doctoral & 13 & $65 \%$ \\
\hline & Other & 0 & $0 \%$ \\
\hline \multicolumn{4}{|c|}{ Teaching } \\
\hline & Tenured/tenure track & 1 & $5 \%$ \\
\hline & Non-tenure track & 1 & $5 \%$ \\
\hline & Adjunct & 5 & $25 \%$ \\
\hline & None & 13 & $65 \%$ \\
\hline \multicolumn{4}{|c|}{ Institution Type } \\
\hline & Public & 11 & $55 \%$ \\
\hline & Private & 9 & $45 \%$ \\
\hline & 2-year & 6 & $35 \%$ \\
\hline & 4-year & 14 & $64 \%$ \\
\hline & For profit & 2 & $10 \%$ \\
\hline & Not for profit & 17 & $89 \%$ \\
\hline \multicolumn{4}{|c|}{ Region } \\
\hline & Northeastern states & 4 & $20 \%$ \\
\hline & Midwestern states & 6 & $30 \%$ \\
\hline & Southern states & 9 & $45 \%$ \\
\hline & Western states & 1 & $5 \%$ \\
\hline
\end{tabular}


Table 2 provides further sample characteristics in terms of mean $(M)$ and standard deviation $(S D)$. When asked in which of the nine areas they have experience (higher education, leadership/management, educational research, faculty development, instructional design, information technology, learning online, teaching online, and teaching face-to-face), COEO respondents reported having experience in most areas $(M=8.5)$. Additionally, when asked which of the eight responsibilities they currently have in their portfolio (mission, accreditation, student demand, faculty needs, curriculum, quality assurance, technology, and resources), COEO respondents reported having jurisdiction over most areas $(M=6.1)$.

\section{Table 2}

Descriptive Statistics for Sample Characteristics

\begin{tabular}{lcc}
\hline \multicolumn{1}{c}{ Sample Characteristics } & $\boldsymbol{M}$ & $\boldsymbol{S D}$ \\
\hline Number of areas in which COEOs have experience & 8.5 & .89 \\
Number of responsibilities under the COEO's current portfolio & 6.1 & 2.17 \\
\hline
\end{tabular}

Table 3 contains descriptive statistics for the quality and power average scores for each of the nine QSC categories. The overall average across all QSC categories was 1.64 for online program quality and 1.66 for legitimate power.

\section{Table 3}

Descriptive Statistics for Quality and Power Average Scores at the QSC Category Level

\begin{tabular}{|c|c|c|c|c|}
\hline \multirow{2}{*}{ QSC Categories } & \multicolumn{2}{|c|}{ Average Quality Score } & \multicolumn{2}{|c|}{ Average Power Score } \\
\hline & $M$ & $S D$ & $M$ & $S D$ \\
\hline QSC 1. Institutional Support & 1.42 & .69 & 1.69 & .66 \\
\hline QSC 2. Technology Support & 1.91 & .72 & 1.54 & .76 \\
\hline QSC 3. Course Development and Instructional Design & 1.48 & .79 & 1.74 & .82 \\
\hline QSC 4. Course Structure & 1.81 & .63 & 1.77 & .86 \\
\hline QSC 5. Teaching and Learning & 1.76 & .68 & 1.52 & 1.01 \\
\hline QSC 6. Social and Student Engagement & 1.45 & .94 & 1.65 & .88 \\
\hline QSC 7. Faculty Support & 1.78 & .78 & 2.12 & .83 \\
\hline QSC 8. Student Support & 1.76 & .52 & 1.55 & .65 \\
\hline QSC 9. Evaluation and Assessment & 1.39 & .59 & 1.36 & .84 \\
\hline Overall Average & 1.64 & .56 & 1.66 & .66 \\
\hline
\end{tabular}

Note. Scores range between zero and three.

\section{Research Question 1}

The first research question explored whether there is a statistically significant correlation between COEOs' overall legitimate power and overall online program quality, as self-assessed by COEOs using the Quality Scorecard (QSC). As shown in Table 4, there is a statistically significant correlation between average power and average quality ( $r$ values ranged from .55 to $.86, p<.05$ ). Average legitimate power had a strong positive effect on average online program quality in each QSC category. 


\section{Table 4}

\section{Correlation Between Overall Average Power and Average Quality}

QSC Category $\quad r \quad p$

\begin{tabular}{rllc}
\hline 1. & Institutional Support & $.66^{* *}$ & .00 \\
2. & Technology Support & $.61^{* *}$ & .00 \\
3. Course Development and Instructional Design & $.71^{* *}$ & .00 \\
4. Course Structure & $.86^{* *}$ & .00 \\
5. Teaching and Learning & $.85^{* *}$ & .00 \\
6. Student and Social Engagement & $.71^{* *}$ & .00 \\
7. & Faculty Support & $.86^{* *}$ & .00 \\
8. Student Support & $.55^{*}$ & .01 \\
9. & $.60^{* *}$ & .00 \\
\hline
\end{tabular}

Note. ${ }^{*} p<.05$ (two-tail); ${ }^{* *} p<.01$ (two-tail).

Table 5 presents the varied relationships between average power and average quality per QSC category. Most, though not all, relationships are statistically significant. All relationships are positive, except those between P6 and Q2, P8 and Q2, and P9 and Q2. Most influential among these strong relationships are those at the level of institutional support (P1), course development/instructional design (P3), and course structure (P4), while the least influential relationship is at the level of technology support (P2).

\section{Table 5}

Correlation Between Average Power and Average Quality (QSC Category Level)

\begin{tabular}{|c|c|c|c|c|c|c|c|c|c|}
\hline $\begin{array}{l}\text { Average } \\
\text { Power }\end{array}$ & Q1 & Q2 & Q3 & Q4 & $\begin{array}{c}r(p) \\
\text { erage Quali } \\
\text { Q5 }\end{array}$ & Q6 & Q7 & Q8 & Q9 \\
\hline P1 & $.66^{* *}(.00)$ & $.47^{*}(.04)$ & $.67^{* *}(.00)$ & $.65^{* *}(.00)$ & $.70^{* *}(.00)$ & $.36 \quad(.12)$ & $.71^{* *}(.00)$ & $.47^{*}(.04)$ & $.71^{* *}(.00)$ \\
\hline $\mathbf{P 2}$ & $.52^{*}(.02)$ & $.61^{* *}(.00)$ & $.40 \quad(.08)$ & $.39 \quad(.09)$ & $.33 \quad(.15)$ & $.19 \quad(.42)$ & $.21 \quad(.37)$ & $.38 \quad(.10)$ & $.48^{*}(.03)$ \\
\hline P3 & $.54^{*}(.01)$ & $.22 \quad(.35)$ & $.71^{* *}(.00)$ & $.82^{* *}(.00)$ & $.83^{* *}(.00)$ & $.46^{*}(.04)$ & $.71^{* *}(.00)$ & $.52^{*}(.02)$ & $.72^{* *}(.00)$ \\
\hline P4 & $.61^{* *}(.01)$ & $.15 \quad(.54)$ & $.73^{* *}(.00)$ & $.86^{* *}(.00)$ & $.80^{* *}(.00)$ & $.56^{*}(.01)$ & $.69^{* *}(.00)$ & $.66^{* *}(.00)$ & $.77^{* *}(.00)$ \\
\hline P5 & .35 (.13) & $.01 \quad(.96)$ & $.56^{* *}(.01)$ & $.79^{* *}(.00)$ & $.85^{* *}(.00)$ & $.65^{* *}(.00)$ & $.66^{* *}(.00)$ & $.54^{*}(.01)$ & $.66^{* *}(.00)$ \\
\hline P6 & $.17 \quad(.47)$ & $-.18 \quad(.45)$ & $.15 \quad(.52)$ & $.52^{*}(.02)$ & $.56^{*}(.01)$ & $.71^{* *}(.00)$ & $.36 \quad(.12)$ & $.43 \quad(.06)$ & $\begin{array}{ll}.41 \quad(.07)\end{array}$ \\
\hline P7 & $.48^{*}(.03)$ & $.24(.30)$ & $.57^{* *}(.01)$ & $.77^{* *}(.00)$ & $.77^{* *}(.00)$ & $.45^{*}(.04)$ & $.86^{* *}(.00)$ & $.44^{*}(.05)$ & $.65^{* *}(.00)$ \\
\hline P8 & $.22(.35)$ & $-.03 \quad(.91)$ & $.32(.17)$ & $.64^{* *}(.00)$ & $.74^{* *}(.00)$ & $.62^{* *}(.00)$ & $.54^{*}(.01)$ & $.55^{*}(.01)$ & $.54^{*}(.01)$ \\
\hline P9 & $.25 \quad(.28)$ & $-.26 \quad(.27)$ & $.44 \quad(.05)$ & $.57^{* *}(.01)$ & $.66^{* *}(.00)$ & $.46^{*}(.04)$ & $.53^{*}(.02)$ & $.37(.11)$ & $.60^{* *}(.00)$ \\
\hline
\end{tabular}

Note. ${ }^{*} p<.05$ (two-tail); ${ }^{* *} p<.01$ (two-tail).

QSC (power [P] and quality [Q]) categories: $1=$ institutional support, $2=$ technology support, $3=$ course development/instructional design, $4=$ course structure, $5=$ teaching and learning, $6=$ social and student engagement, 7 = faculty support, $8=$ student support, $9=$ evaluation and assessment. 


\section{Research Question 2}

The second research question explored whether there is a statistically significant correlation between COEOs' perceived overall legitimate power and COEO-reported environmental factors. As shown in Table 6, the correlation coefficients ranged from -.37 to .66, with the only statistically significant correlation between the COEO's job title (E1) and overall legitimate power.

\section{Table 6}

\section{Correlation Between Environmental Factors and Average Power}

Environmental Factors $\quad r \quad p$

\begin{tabular}{lll}
\hline E1. COEO's job title (hierarchy) & $.66^{* *}$ & .00 \\
E2. The job title of the COEO's supervisor (hierarchy) & .3 & .18 \\
E3. Units making a partial or full report to the COEO (number) & .38 & .10 \\
E4. COEO role existence at the respondents' institutions (duration) & .04 & .87 \\
E5. Public or private institution & .02 & .94 \\
E6. For- or non-profit institution & -.41 & .08 \\
E7. 2- or 4-year institution & -.25 & .29 \\
E8. Institution's Carnegie classification & -.37 & .15 \\
E9. Highest degree earned by the COEO & .30 & .20 \\
E10. Length of experience as COEO, including current employment & .18 & .44 \\
E11. Number of areas in which the COEO has any degree of experience & .17 & .48 \\
E12. Current responsibility portfolio & .42 & .07 \\
E13. Teaching responsibility at the current institution & .13 & .58 \\
E14. Age & .01 & .95 \\
E15. Gender & .32 & .17 \\
\hline
\end{tabular}

Note. ${ }^{* *} p<.01$ (two-tail).

Table 7 shows the relationships between the various environmental factors and average legitimate power observed within each of the nine QSC categories, with wide variations in the magnitude and direction of correlations (ranging from -.58 to .73). Seven environmental factors (E1, E3, E4, E6, E8, E9, and E12) hold statistically significant correlations with at least one average power value, as detailed below. Of these factors, most impactful are the COEO job title (hierarchy, E1) and the number of units reporting to the COEO (E3).

Looking across the $\mathrm{E} 1$ row in Table 7 , data indicate a statistically significant association between the COEO job title hierarchy and institutional support ( $\left.\mathrm{P} 1 r_{s}=.48, p<.05\right)$, course development/instructional design $\left(\mathrm{P} 3 r_{s}=.61, p<.01\right)$, course structure $\left(\mathrm{P} 4 r_{s}=.66, p<.01\right)$, teaching and learning (P5 $\left.r_{s}=.60, p<.01\right)$, social and student engagement $\left(\mathrm{P} 6 r_{s}=.48, p<.05\right)$, faculty support (P7 $\left.r_{s}=.73, p<.01\right)$, student support (P8 $\left.r_{s}=.55, p<.05\right)$, as well as evaluation and assessment (P9 $\left.r_{s}=.64, p<.01\right)$. The E3 row reveals a statistically significant association between the number of units making a partial or full report to the COEO and institutional support $(\mathrm{P} 1 r=.57, p<.01)$, technology support $(\mathrm{P} 2 r=.49, p<.05)$, as well as faculty support (P7 $r=$ $.57, p<.01)$. Data in the E4 row indicate a statistically significant association between the length of time the COEO role existed at the respondents' institutions and technology support ( $\mathrm{P} 2 r=.55$, $p<.05)$. Data in the E6 row indicates the presence of a statistically significant correlation between the for- or non-profit status of institutions and course development/instructional design (P3 $r=$ $.49, p<.05)$. Row E8 indicates a statistically significant correlation between the institution's 
Carnegie classification and course structure ( $\left.\mathrm{P} 4 r_{s}=.58, p<.05\right)$. Data in row E9 point out a statistically significant correlation between the highest degree earned by the COEO and faculty support $\left(\mathrm{P} 7 r_{s}=.46, p<.05\right)$. Lastly, row E12 indicates the presence of a statistically significant correlation between the COEO's current responsibility portfolio and course structure $(\mathrm{P} 4 r=.51$, $p<.05)$ as well as faculty support $(\mathrm{P} 7 r=.63, p<.01)$.

\section{Table 7}

Correlation Between Environmental Factors and Average Power

\begin{tabular}{|c|c|c|c|c|c|c|c|c|c|}
\hline \multirow[b]{2}{*}{$\mathbf{E}$} & \multicolumn{9}{|c|}{ Correlation Coefficient (Significance) } \\
\hline & P1 & $\mathbf{P 2}$ & P3 & P4 & P5 & P6 & P7 & P8 & P9 \\
\hline $\mathrm{E} 1^{\mathrm{a}}$ & $.48^{*}(.03)$ & $.00(.99)$ & $.61^{* *}(.01)$ & $.66^{* *}(.00)$ & $.60^{* *}(.01)$ & $.48^{*}(.02)$ & $.73^{* *}(.00)$ & $.55^{*}(.01)$ & $.64^{* *}(.00)$ \\
\hline $\mathrm{E} 2^{\mathrm{a}}$ & $.14(.55)$ & $.27(.25)$ & $.20(.40)$ & $.19(.44)$ & $.31 \quad(.18)$ & $.33(.16)$ & $.35(.13)$ & $.27(.26)$ & $.17 \quad(.47)$ \\
\hline$E 3^{\mathrm{b}}$ & $.57^{* *}(.01)$ & $.50^{*}(.03)$ & $.43(.06)$ & $.37(.11)$ & $.20 \quad(.39)$ & $-.01(.96)$ & $.57^{* *}(.01)$ & $.19(.43)$ & $.07 \quad(.77)$ \\
\hline $\mathrm{E} 4^{\mathrm{a}}$ & $.41 \quad(.10)$ & $.55^{*}(.02)$ & $.34(.18)$ & $.01 \quad(.97)$ & $.05 \quad(.85)$ & $-.34(.18)$ & $-.02(.94)$ & $-.20(.45)$ & $-.03(.92)$ \\
\hline $\mathrm{E} 5^{\mathrm{b}}$ & $-.26(.27)$ & $-.07(.76)$ & $.05(.85)$ & $.11 \quad(.65)$ & $.05 \quad(.82)$ & $.02(.94)$ & $-.17 \quad(.47)$ & $-.10(.69)$ & $.13(.58)$ \\
\hline $\mathrm{E} 6^{\mathrm{b}}$ & $-.18(.45)$ & $-.36(.13)$ & $-.49^{*}(.03)$ & $-.40 \quad(.09)$ & $-.33 \quad(.17)$ & $-.13(.61)$ & $-.36(.13)$ & $-.31(.19)$ & $-.42(.07)$ \\
\hline$E 7^{b}$ & $-.19(.43)$ & $-.03(.90)$ & $-.16(.50)$ & $-.20 \quad(.40)$ & $-.14 \quad(.55)$ & $-.27(.25)$ & $-.33 \quad(.15)$ & $-.30(.20)$ & $-.22(.36)$ \\
\hline$E 8^{a}$ & $-.24(.36)$ & $-.16(.53)$ & $-.36(.16)$ & $-.58^{*}(.02)$ & $-.20 \quad(.43)$ & $-.47(.06)$ & $-.29 \quad(.27)$ & $-.25(.34)$ & $-.29(.26)$ \\
\hline $\mathrm{E9}^{\mathrm{a}}$ & $.27(.24)$ & $-.17(.46)$ & $.40(.08)$ & $.27 \quad(.24)$ & $.28 \quad(.24)$ & $.17(.46)$ & $.46^{*}(.04)$ & $.27(.24)$ & $.32(.17)$ \\
\hline $\mathrm{E} 10^{\mathrm{a}}$ & $.17(.48)$ & $.20(.40)$ & $.38(.10)$ & $.30 \quad(.20)$ & $.27 \quad(.25)$ & $.03(.90)$ & $.12(.60)$ & $-.07(.77)$ & $.29(.21)$ \\
\hline $\mathrm{E} 11^{\mathrm{b}}$ & $.04(.87)$ & $.29(.21)$ & $.09(.71)$ & $.17 \quad(.48)$ & $.05 \quad(.84)$ & $.30(.19)$ & $.07 \quad(.77)$ & $.12(.61)$ & $.09(.71)$ \\
\hline $\mathrm{E} 12^{\mathrm{b}}$ & $.41(.07)$ & $.12(.63)$ & $.44(.05)$ & $.51^{*}(.02)$ & $.29 \quad(.21)$ & $.16(.51)$ & $.63^{* *}(.00)$ & $.18(.45)$ & $.30(.20)$ \\
\hline $\mathrm{E} 13^{\mathrm{a}}$ & $.28(.24)$ & $.21(.37)$ & $.12(.60)$ & $-.11(.63)$ & $.08 \quad(.72)$ & $-.13(.59)$ & $.29 \quad(.22)$ & $.25(.28)$ & $.11(.64)$ \\
\hline $\mathrm{E} 14^{\mathrm{a}}$ & $-.19(.43)$ & $-.19(.43)$ & $.03(.91)$ & $.18 \quad(.44)$ & $.14 \quad(.55)$ & $-.03(.92)$ & $-.12(.62)$ & $-.21(.38)$ & $.07(.77)$ \\
\hline $\mathrm{E} 15^{\mathrm{b}}$ & $.43(.06)$ & $.38(.10)$ & $.30(.20)$ & $.16 \quad(.49)$ & $.29(.21)$ & $.10(.67)$ & $.34 \quad(.15)$ & $.17(.48)$ & $.19(.43)$ \\
\hline
\end{tabular}

Note. ${ }^{*} p<.05$ (two-tail); ${ }^{* *} p<.01$ (two-tail).

$\mathrm{a}=$ Analyzed through Spearman rho's correlation $(r s) ; \mathrm{b}=$ Analyzed through Pearson's correlation $(r)$.

$\mathrm{E}=$ Environmental factors; E1 = COEO's job title (hierarchy); E2 = the job title of the COEO's supervisor (hierarchy); $\mathrm{E} 3$ = units making a partial or full report to the COEO (number); E4 = COEO role existence at the respondents' institutions (duration); E5 = public or private institution; E6 = for- or non-profit institution; E7 = 2- or 4-year institution; E8 = institution's Carnegie classification; E9 = highest degree earned by the COEO; E10 = length of experience as COEO, including current employment; E11 = number of areas in which the COEO has any degree of experience; E12 = current responsibility portfolio; E13 = teaching responsibility at the current institution; E14 = age; $\mathrm{E} 15=$ gender.

P1 = institutional support; P2 = technology support; P3 = course development/instructional design; P4 = course structure; P5 = teaching and learning; P6 = social and student engagement; P7 = faculty support; P8 = student support; $\mathrm{P} 9=$ evaluation and assessment.

\section{Discussion}

When examining the correlation between the COEOs' overall legitimate power and overall online program quality, as self-assessed by COEOs using the QSC, the study found overall power had a positive effect on overall quality. When examined at the QSC category level, power and quality were strongly correlated, except when it came to how quality in technology support (Q2) relates to power in social and student engagement (P6), student support (P8), and evaluation and assessment (P9). This finding is consistent with the Fredericksen $(2017,2018)$ studies which indicated online education is not an IT function; rather, institutions depend on the IT unit to provide a platform for learning and engagement. 
Knowing overall power has a strong positive effect on overall quality, it would be advisable for senior leaders to consider crafting their COEO's job description such that power levels are commensurate with the desired quality levels for which the hired COEO will be responsible. As Herron et al. (2016) recommend, to fully empower the COEO, senior leadership may wish to place their institution's COEOs on equal footing with the CIO and CFO, with a direct report to the president. Moreover, when the senior leaders strategically set a specific quality standard for their institution's existing or future online programs, it would be advisable for them to also assign corresponding power levels to their COEO. For instance, it would be very difficult for a COEO tasked with assuring exceptional quality levels of course development and instructional design not to have full authority over online course development and instructional design efforts at the institution.

When examining the correlation between the COEOs' perceived overall legitimate power at their institution and COEO-reported environmental factors, the study identified a statistically significant correlation between the COEO's job title (E1) and overall power. Therefore, senior leadership may wish to assign their COEO a job title commensurate with the power level necessary to enact the desired quality level. In other words, the more critical the online program is to the institution, the higher the COEO would need to be placed within the organizational chart.

At the QSC category level, at least one of the nine average power values displayed strong positive correlation with COEO job title hierarchy (E1), units making a partial or full report to the COEO (E3), the length of time the COEO role existed at the respondents' institutions (E4), for- or non-profit status of institutions (E6), the institution's Carnegie classification (E8), the highest degree earned by the COEO (E9), and the COEO's current responsibility portfolio (E12). Factors E1, E3, E4, E9, are E12 are generally within the purview of senior leadership. Therefore, presidents and provosts may wish to consider increasing their COEO's authority over quality by assigning a higher title on the organizational chart for this officer, by putting their COEO in charge of a higher number of reporting units, and by delegating a broader portfolio of responsibilities to this role. For institutions that have not yet created a COEO-type role but have an investment in online programs, it would be advisable to create this role and to design responsibilities commensurate with institutional goals for online education quality.

This study enacted Dr. Kaye Shelton's recommendation of asking COEOs to self-assess their institution's online programs (2010). By replicating inquiry into some of the COEO characteristics that were the objects of previous studies, this research also adds to the small but growing body of literature focused on the American COEO higher education population. For instance, consistent with previous observations of COEO title variations (Fredericksen, 2017; Legon \& Garett, 2017; Nworie, 2012), data from this study shows seven variations of the COEOs title, including chief officer, provost, vice president, dean, director, analyst, and coordinator. In another example, when it comes to the COEOs' upstream reporting line, this study indicated chief online education officers report to a variety of roles, primarily the provost $(50 \%)$, followed by vice presidents $(15 \%)$, deans $(10 \%)$, chief officers $(10 \%)$, and the president $(10 \%)$. These findings are consistent with the results of the Fredericksen (2017) study, which indicated COEOs report mostly to the provost $(52 \%)$, followed by other senior academic leaders $(23 \%)$, vice presidents (7\%), chief information officers $(5 \%)$, the president $(5 \%)$, and deans $(3 \%)$. However, these upstream reporting lines fall short of the expectations laid out by Herron, Lashley, Salley, and Shaw (2016), who advocate for COEOs to be part of the chief officer suite and thus report directly to the president. 


\section{Limitations}

Of the 1,572 known COEOs in the United States (Fredericksen, 2017; 2018), this study was only able to elicit 20 responses compared to the 104 responses achieved by CHLOE (Legon $\&$ Garrett, 2017). While this limitation can be attributed to the nascent nature of this type research and to the challenge of reaching this population absent a national list of COEO contacts, it is still important to emphasize that the study's low response rate does not allow for predictive analysis. Additionally, while there are several ways to design a study meant to investigate the COEO's legitimate power over online program quality in U.S. higher education institutions, the author opted to begin exploration of this research vein by obtaining answers directly from COEOs. Therefore, COEOs self-selected for participation in this study and described their institution's context based on their own knowledge. They also used their own perceptions to assess their institution's online program quality outside the confines of a typical QSC peer review team. Furthermore, they self-assessed their role's legitimate power over each QSC quality indicator. Results are thus limited to a COEO-centric reality.

\section{Implications for Future Research}

Future research could "paint a more holistic picture" by including the perspectives of those working closest with COEOs, such as their leadership, peers, and subordinates. Quality in online program administration could also be explored through the broad lens of influence or the more granular lens of all six power bases. Furthermore, the American higher education community would benefit from forming a centralized COEO home base to more easily connect COEOs with one another for collaboration and mentorship purposes, to put professional-development resources at COEO's fingertips, and to give researchers gated access to this population. With broader access to COEOs, studies similar could achieve higher response rates, permit significant predictions, and ultimately allow senior leadership to more accurately calibrate their COEO's legitimate power.

\section{Conclusions}

This study responds to the lack of research around how the legitimate power granted to COEOs correlates with the quality of online programs and unique institutional contexts. Presidents/chancellors and provosts need to ground their practice in research as they empower their COEO to successfully influence the quality of online programs.

This study's results can be used to maximize quality in online programs by calibrating the COEO's levels of legitimate power. Senior leadership can use this article to inform how to allocate COEO power to maximize online program quality. For instance, most impactful to an online program's quality are designating to the COEO greater authority over instructional support (P1), course development/instructional design (P3), and course structure (P4), as these three categories are shown to be strongly correlated with an increase in overall quality. Senior leadership can also use this article to inform more granular quality decisions. For example, if the institution's strategic goal is to lead the industry through outstanding faculty support, placing the COEO's title as high as possible in the organizational chart (E1), increasing the number of units reporting to the COEO (E3), and expanding the COEO's portfolio of responsibilities (E12) are shown be strongly correlated with an increased quality of faculty support (Q7).

The study may be of interest to several entities in higher education institutions in America, including: 
- senior leadership provisioning for and supervising COEOs, typically the president, chancellor, or provost;

- COEOs, themselves, to benchmark their role and legitimize power against the findings in this study;

- professionals with some responsibility over online education leadership who are looking to justify requesting additional authority to reach COEO levels in order to more effectively foster quality in the administration of online education;

- internal stakeholders working closely with COEOs to assure quality, such as the chief information officer, chief financial officer, chief academic/learning officer, vice presidents, vice chancellors, deans, chairs, program directors, faculty, etc.; and

- external stakeholders working closely with COEOs to assure quality, such as governance bodies, accreditation bodies, or national reporting organizations.

Although gaps in the literature remain - particularly regarding what enables a COEO to successfully drive quality in online education - there are promising activities both in practice and inquiry that can maximize the impact of COEOs in American online higher education. Such promising efforts include, but are not limited to, research examining how leadership theories apply to COEO-type roles (Nworie, 2012), research resulting in an instrument for measuring quality in online programs (Shelton, 2010), research describing the COEO population and its environment (Fredericksen, 2017, 2018), research examining what makes a COEO successful (Herron et al., 2016), research capturing the voice of COEOs in the context of the changing landscape of online education (Legon \& Garrett, 2017; 2018 Legon, Garrett, \& Fredericksen, 2019; 2020; Legon, Garrett, Fredericksen, \& Simunich, 2020), publications offering best practices for the COEO-type role (Hillman, Schudy, \& Temkin, 2020; Piña \& Huett, 2016; Piña, Lowell, \& Harris, 2018; Shelton $\&$ Saltsman, 2005), national conferences delineating online education leadership as an audience (DLA, 2019; OLC Accelerate, 2020; USDLA, 2020), the UPCEA Online Leadership Roundtable initiative (2020), and a National Council for Online Education formed in 2020 in response to the pandemic.

To conclude, this research echoes the call made by Piña \& Huett (2016), for COEO-type professionals to conduct research to inform the practices of online higher education leaders. Since COEOs are a relatively new and scattered group of higher-education professionals, there is a need to create a unifying national COEO home base. The home base would not only generate a national COEO contact list similar to the list of chief academic officers offered by ACAO (n.d.) but would also enable COEOs to collaborate with one another in research, practice, and advocacy. 


\begin{abstract}
Afterword
While this study was pre-pandemic, the need for a professional to oversee distance learning became more evident than ever in the spring of 2020. 68\% of 308 institutions surveyed in CHLOE 5 entrusted a single senior leader with navigating the COVID-19 crisis, and in 13\% of cases, that professional was a COEO (Legon, Garrett, Fredericksen, \& Simunich, 2020). As institutions struggled to navigate multiple complex challenges in meeting the needs of learners without setting foot on campus, the stark contrast between the quality feasibly achievable through emergency remote instruction versus the quality achieved in online courses became apparent (Immerwahr, Johnson, \& Gasbarra, 2008; Legon, Garrett, Fredericksen, \& Simunich, 2020). It is critical for institutions to employ an online education expert who not only knows how to foster quality but can do so without compromising on access and cost. Given the COEOs' broad portfolio and downstream reporting lines (Fredericksen, 2017, 2018), and since COEOs are adept at education, technology, finances, and leadership (Herron et al., 2016), they are the ideal professional to be entrusted with navigating the institution's pandemic response.
\end{abstract}




\section{References}

Adair, D. \& Diaz, S. (2014). Stakeholders of quality assurance in online education. In K., Shattuck (Ed.), Assuring quality in online education: Practices and processes at the teaching, resource, and program levels (pp. 3-17). Sterling, VA: Stylus Publishing, L.L.C.

Allen, I. E. \& Seaman, J. (2004, November). Entering the mainstream: The quality and extent of online education in the United States, 2003 and 2004. [Online Learning Consortium Report]. https://secure.onlinelearningconsortium.org/publications/survey lentering the mainstream 2004

Allen, I. E. \& Seaman, J. with Poulin, R. \& Strout, T. T. (2016, February). Online report card: Tracking online education in the United States. [Babson Survey Research Group Report]. onlinelearningsurvey.com/reports lonlinereportcard.pdf

ACAO (n.d.). Association of Chief Academic Officers: Membership. https://www.acao.org/index.php?option $=$ com mcsearchresults\&view=search\&uuid $=\mathrm{dc} 8 \mathrm{dc} 797$ $\underline{\mathrm{d} 667-469 \mathrm{~b}-9 \mathrm{a} 66-52 \mathrm{e} 59 \mathrm{c} 7 \mathrm{cb} 4 \mathrm{ee} \# /}$

Beaudoin, M. F. (2003). Distance education leadership for the new century. Online Journal of Distance Learning Administration, 6(2).

https://www.westga.edu/ distance/ojdla/summer62/beaudoin62.html

Birnbaum, R. (1989). How colleges work: The cybernetics of academic organization and leadership. San Francisco, CA: Jossey-Bass.

DLA (2019). Distance learning administration conference. https://www.westga.edu/ distance/dla/

Fredericksen, E. (2017, June). A national study of leadership for online learning in U.S. higher education. Online Learning Journal 21(2). https://doi.org/10.24059/olj.v21i2.1164

Fredericksen, E. (2018). A national study of online learning leaders in U.S. community colleges. Online Learning Journal 22(4), 383-405. https://doi.org/10.24059/olj.v22i4.1458

French, J. R. \& Raven, B. H. (1959a). Leadership Power Bases. In J. T. McMahon (Ed.), Leadership Classics (375-389). Long Grove, IL: Waverland Press, Inc.

French, J. R. \& Raven, B. H. (1959b). The bases of social power. In D. Cartwright (Ed.), Studies in social power (pp. 259-269). Ann Arbor, MI: Institute for Social Research.

Herron, J., Lashley, J., Salley, W., \& Shaw, M. (2016). The chief online learning officer: Competencies, roles, and trajectories. UNBOUND: Reinventing Higher Education. https://unbound.upcea.edu/online-2/online-education/the-chief-onlinelearning-officer-competencies-roles-and-trajectories/

Hersey, P., Blanchard, K. H. \& Johnson, D. E. (2018). Management of organizational behavior (p. 131). Princeton, NJ: Pearson Prentice-Hall. 
Hillman, D., Schudy, R., \& Temkin, A. (2020). Best practices for administering online programs. New York, NY: Routledge.

Huett, J. B. \& Piña, A. A. (2016). Preface: Beyond the online course. In A. A. Piña \& J. B. Huett (Eds.). (2016). A volume in perspectives in instructional technology and distance education. Beyond the online course: Leadership perspectives on e-learning (p. xiv). Charlotte, NC: Information Age Publishing.

Immerwahr, J., Johnson, J., \& Gasbarra, P. (2008). The iron triangle: College presidents talk about costs, access, and quality. A report from the National Center for Public Policy and Higher Education Public Agenda. https://www.highereducation.org/ reports/iron_triangle/IronTriangle.pdf

Irele, M. E. (2013). Evaluating distance education in an area of internationalization. In M. G. Moore (Ed.). (2013). Handbook of distance education (p. 504). New York, NY: Routledge.

Johnson, B. \& Christensen, L. B. (2017). Educational research: quantitative, qualitative, and mixed approaches (6th ed.). Thousand Oaks, CA: SAGE Publications, Inc.

Kipnis, D., \& Schmidt, S. M. (1983). An influence perspective on bargaining within organizations. In M. H. Bazerman \& R. J. Lewicki (Eds.), Negotiating in organizations (pp. 303-319). Beverly Hills, CA, Sage.

Kipnis, D., Schmidt, S. M., \& Wilkinson, I. (1980). Interorganizational influence tactics: Explorations of getting one's way. Journal of Applied Psychology, 65, 440-452.

Latchem, C. (2014). Quality assurance in online distance education. In T. Anderson and O. ZawackiRichter (Eds.), Online distance education: Towards a research agenda (pp. 311-342). Edmonton, AB: AU Press.

Lawrence, P. R. \& Lorsch, J. W. (1967). Organization and environment: Managing differentiation and integration. Boston, MA: Graduate School of Business Administration, Harvard University.

Legon, R. \& Garrett, R. (2017). The changing landscape of online education (CHLOE). Quality Matters \& Eduventures survey of chief online officers. [Quality Matters and Eduventures Report] https://www.qualitymatters.org/qa-resources/resource-center/articlesresources/CHLOE-report-2017

Legon, R. \& Garrett, R. (2018). CHLOE 2: The changing landscape of online education: A deeper dive. [Quality Matters and Eduventures Report] https://www.qualitymatters.org/qaresources/resource-center/articles-resources/CHLOE-2-report-2018

Legon, R. Garrett, R. \& Fredericksen, E. (2019). CHLOE 3: Behind the numbers. The changing landscape of online education. Quality Matters \& Eduventures survey of chief online officers. [Quality Matters and Eduventures Report] https://www.qualitymatters.org/qaresources/resource-center/articles-resources/CHLOE-3-report-2019 
Legon, R. Garrett, R. \& Fredericksen, E. E. (2020). CHLOE 4: Navigating the mainstream. The changing landscape of online education, 2020. Quality Matters \& Eduventures survey of chief online officers. [Quality Matters and Eduventures Report] https://www.qualitymatters.org/qaresources/resource-center/articles-resources/CHLOE-4-report-2020

Legon, R., Garrett, R., Fredericksen, E. E., \& Simunich, B. (2020). CHLOE 5: The pivot to remote teaching in spring 2020 and its impact. The changing landscape of online education, 2020. Quality Matters \& Eduventures survey of chief online officers. [Quality Matters and Eduventures Report] Retrieved from https://www.qualitymatters.org/qa-resources/resourcecenter/articles-resources/CHLOE-5-report-2020

Lunenburg, F.C. (2012). Power and leadership: An influence process. International Journal of Management, Business and Administration, 15(1), 1-9. http://www.nationalforum.com/Electronic\%20Journal\%20Volumes/Lunenburg, $\% 20$ Fred $\% 20$ C\%20Power\%20and\%20LeadershipAn\%20Influence\%20Process \%20IJMBA\%20V15\%20N1\%202012.pdf

Manning, K. (2013). Core concepts in higher education: Organizational theory in higher education. New York, NY: Routledge.

Matteson, M. T. \& Ivancevich, J. M. (1998). Management and organizational behavior classics. New York: Irvin-McGraw Hill.

Merisotis, J. P. \& Phipps, R. A. (2000, May). Quality on the line: Benchmarks for success in internet-based distance education. [Institute for Higher Education Policy Report]. http://www.ihep.org/research /publications/quality-line-benchmarks-success-internet-based-distance-education

Mitchell, B. \& Geva-May, I. (2009). Attitudes affecting online learning implementation in higher education institutions. Journal of Distance Education, 23(1), 71-88. https://pdfs.semanticscholar.org/be7e/18a643077ab27f99809b8dc175c29b9f45db.pdf

National Council for Online Education (2020). About the NCOE. https://www.nationalcouncil.online/about

Neter, J., Wasserman, W., \& Kutner, M. H. (1990). Applied linear statistical models. Regression, analysis of variance and experimented designs (3rd ed.). Homewood, IL: Richard D. Irwin.

Nworie, J. (2012). Applying leadership theories to distance education leadership. Online Journal of Distance Learning Administration, 15(5). http://www.westga.edu I distance/ojdla/winter154/nworie154.html

OLC (2018). OLC quality scorecard for the administration of online programs. [Scorecard] https://onlinelearningconsortium.org/consult/olc-quality-scorecard-administration-onlineprograms/

OLC Accelerate (2020). Accelerating online learning worldwide: https://onlinelearningconsortium.org/attend-2020/accelerate/ 
Palloff, R. \& Pratt, K. (2005). Foreword. In K. Shelton \& G. Saltsman. (2005). An administrator's guide to online education. Greenwich, CT: Information Age Publishing, p. vii.

Piña, A. A., Lowell, V. L., \& Harris, B. R. (Eds.). (2018). Leading and managing e-learning: What the e-learning leader needs to know. Cham, Switzerland: Springer.

Podsakoff, P. M., \& Schriesheim, C. A. (1985). Field studies of French and Ranven's bases of power: Critiques, reanalysis, and suggestions for future research. Psychological Bulletin, 97(3), 387-411.

Quality Matters (2017, May 31). Press release: Online learning goes mainstream. https://www.qualitymatters.org/qa-resources/resource-center/articles-resources lqm-eduventures-chloe

Raosoft (2004). Sample size calculator. [Software] http://www.raosoft.com/samplesize.html

Raven, B. H. (1965). Social influence and power. In I. D. Steiner \& M. Fishbein (Eds.), Current studies in social psychology (pp. 371-382). New York, NY: Holt, Rinehart, \& Winston.

Robbins, E. (2009). Organizational behavior (p. 508). India: Pearson Education.

Shattuck, K. (Ed.). (2014). Assuring quality in online education: Practices and processes at the teaching, resource, and program levels. Sterling, VA: Stylus Publishing L.L.C.

Shelton, K. \& Saltsman, G. (2005). An administrator's guide to online education. Greenwich, CT: Information Age Publishing.

Shelton, K. (2010a). A quality scorecard for the administration of online education programs: A Delphi study (Doctoral dissertation, University of Nebraska - Lincoln). Educational Administration: Theses, Dissertations, and Student Research. 39. https://digitalcommons.unl.edu/cgi/viewcontent.cgi?referer=https://www.google.com/\&httpsr $\underline{\text { edir }=1 \& \text { article }=1039 \& \text { context }=\text { cehsedaddiss }}$

Shelton, K. (2010b). A quality scorecard for the administration of online education programs: A Delphi study. Journal of Asynchronous Learning Networks 14(4), 36-62. http://www.anitacrawley.net/Resources/Articles/sheltonqualityscorecard.pdf

Thompson, L. (2003). The social psychology of organizational behavior: Key readings (p. 16). New York: Psychology Press.

UPCEA (2020). Online leadership roundtable (OLR): A forum for chief online learning officers. https://upcea.edu/leaders-in-online-education/

USDLA. (2020). Grooving globally with digital and distance learning. https://usdla.org/2020national-conference/ 